\title{
一般 38
}

\section{マウス脳内URAT1 は脳室上衣細胞脳室側膜に局在する}

\section{目的}

尿酸は多発性硬化症, パーキンソン病, アルッ ハイマー病などの神経変性疾患に対して保護作用 を持つことが疫学的に示されており,パーキンソ ン病モデルマウスでは尿酸による黒質線条体ドパ ミン神経細胞保護作用が示されている。脳におけ る尿酸動態を明らかにするため, マウス脳内の URAT1局在部位について検討した.

\section{方 法}

URAT1ノックアウトマウス（URAT1-KOマ ウス）との比較によりマウス脳内URAT1発現部 位を免疫組織化学および免疫蛍光染色により明ら かにした。

\section{結果}

1) URAT1の染色は脳室と脳実質の境界を形 成する脳室上衣細胞の脳室側膜および線毛に発現 が認められ，URAT1-KOマウスでは同部位の染 色が消失していた，2）脳脈絡叢および脳実質で はURAT1-KOマウスと同じ非特異的染色が認め られた，3）腹側第3脳室でのURAT1発現は上 部の脳室上衣細胞に局在し，下部のtanycyteに は発現を認めなかった，4）各脳室部位で発現す るが, 中脳水道のURAT1発現量が最も高いと考 えられた５）線毛マーカーの抗アセチル化 $\alpha$ -

\author{
富岡 直子 1)
}

森崎隆幸3)

中村真希子 2)

内田 俊也 ${ }^{4}$

市田 公美 22

細山田 真 ${ }^{1)}$

チューブリン抗体との蛍光二重染色により, URAT1-KOマウスにおけるURAT1蛍光の消失 は線毛の消失によるものではなかった。

\section{考察}

1.以前の報告にある脳脈絡叢および脳毛細血 管におけるURAT1発現については今回の検討で は認められなかった。脳室上衣細胞における URAT1の発現は本研究が初めての報告である. 2. 脳室上衣細胞内の乳酸濃度は脳脊髄液より高 いと考えられ，URAT1は脳脊髄液内の尿酸を脳 実質に交換輸送する可能性がある。 3 ．脳室上衣 細胞はグルタチオンなど抗酸化物質の集積があ り, 脳脊髄液の流れを生成する脳室上衣細胞の線 毛運動に尿酸の抗酸化作用が必要である可能性が ある.4．脳毛細血管管腔側にABCG2の発現が 示されていることから, URAT1により脳春髄液 から脳実質へ輸送された尿酸が，ABCG2により 脳実質から脳毛細血管へ排泄されている可能性が 考えられる。

\section{結語}

マウス脳室上衣細胞脳室側にURAT1が発現 し, 脳脊髄液から脳実質への尿酸輸送を行ってい る可能性が示された。
1 ) 帝京大 $\cdot$ 薬 $\cdot$ 人体機能形態学
2) 東京薬科大 · 病態生理学
3) 国循セ研・バイオサイエンス部
4 ) 帝京大・医・内科学

Naoko Tomioka, Makoto Hosoyamada

Makiko Nakamura, Kimiyoshi Ichida

Takayuki Morisaki

Syunya Uchida 